\title{
Ichthyofauna of the Ribeirão Frutal and tributaries, upper Rio Paraná basin, Minas Gerais, Southeastern Brazil
}

\author{
Valter M. Azevedo-Santos ${ }^{1 *}$ () , Paula N. Coelho ${ }^{I} \&$ Gabriel de Carvalho Deprá ${ }^{2}$ \\ ${ }^{I}$ Universidade Estadual Paulista 'Júlio de Mesquita Filho', Instituto de Biociências - Zoologia, \\ Botucatu, SP, Brasil \\ ${ }^{2}$ Universidade Estadual de Maringá, Maringá, PR, Brasil \\ *Corresponding author: Valter M. Azevedo-Santos, e-mail: valter.ecologia@gmail.com
}

\begin{abstract}
AZEVEDO-SANTOS, V. M., COELHO, P.N., DEPRÁ, G.C. Ichthyofauna of the Ribeirão Frutal and tributaries, upper Rio Paraná basin, Minas Gerais, Southeastern Brazil. Biota Neotropica. 18(3): e20180517. http://dx.doi. org/10.1590/1676-0611-BN-2018-0517
\end{abstract}

\begin{abstract}
The Ribeirão Frutal basin is located within the upper Rio Paraná system, in the Frutal municipality, Minas Gerais State, Southeastern Brazil. Until now, there was no complete ichthyological survey published for this small basin. Therefore, here we provided a list of fish species from the Ribeirão Frutal and some of its tributaries. We found 31 species of fishes representing five orders and ten families. We identify a likely undescribed and five non-native species in the Frutal basin. Lastly, we recommend new surveys of fishes in small hydrographic basins within upper Rio Paraná system.
\end{abstract}

Keywords: Ichthyology, inventory, Neotropical region, Rio Grande, survey.

\section{Ictiofauna do Ribeirão Frutal e afluentes, bacia do alto Rio Paraná, Minas Gerais, Sudeste do Brasil}

\begin{abstract}
Resumo: A bacia do Ribeirão Frutal está localizada no sistema do alto Rio Paraná, no município de Frutal, Estado de Minas Gerais, Sudeste do Brasil. Até o momento, não existe publicação de um levantamento ictiológico completo para essa bacia. Portanto, aqui fornecemos uma lista das species de peixes do Ribeirão Frutal e alguns de seus tributários. Nós encontramos 31 espécies de peixes representando cinco ordens e 10 famílias. Identificamos uma provável espécie não descrita e cinco não nativas na bacia do Frutal. Por fim, recomendamos novos levantamentos de peixes em pequenas bacias hidrograficas do sistema do alto Rio Paraná.
\end{abstract}

Palavras-chave: Ictiologia, inventário, levantamento, região Neotropical, Rio Grande.

\section{Introduction}

Ichthyological surveys, also referred to in scientific literature as inventories (e.g., Giongo et al. 2011; Vidotto-Magnoni et al. 2015), are performed in order to assess the biodiversity of a stream, river or lake (Silveira et al. 2010). Consequently, these studies may result in new discoveries (e.g., undescribed species) and can be implemented as the basis for conservation actions (e.g., Castro et al. 2004, Serra et al. 2007, Raiol et al. 2012, Ohara \& Loeb 2016, Silva-Oliveira et al. 2016, Melo et al. 2016, Ferreira et al. 2017).

The Ribeirão Frutal basin is a tributary of the Rio Grande, in the upper Rio Paraná system, Minas Gerais State (Triângulo Mineiro), Brazil. This small basin (with just over $120 \mathrm{Km}^{2}$ ) (Machado \& Audino 2017) has been impacted by several anthropogenic disturbances (see Machado \& Audino 2017; and Brito et al. 2017 and references therein). Recently, a truck leaked a substantial volume of hydrochloric acid into one of its tributaries, the Vertente Grande, killing a large number of its aquatic organisms (Azevedo-Santos \& Coelho, pers. obs.). Another threat, for instance, is the advancement of the urban area of the Frutal municipality, which may compromise the water quality of the lower Ribeirão Frutal. Despite being located in a relatively well-populated region, there has been no comprehensive survey of its fish fauna until now. In order to understand the ichthyofauna from this small basin facing numerous threats due to anthropogenic development, we here provided a survey of fish species that occur in the Ribeirão Frutal and some of its tributaries.

\section{Material and methods}

Samplings were carried April, May, August, and October 2017, using handnets (mesh of $1.5 \mathrm{~mm}$ ), a small trawl (mesh of $1.5 \mathrm{~mm}$ ), and gill nets ( 10 and $20 \mathrm{~mm}$ between opposite nodes). Collections involved 
the efforts of two researchers during daytime and, when possible, in the evening. A total of 10 localities were sampled in the Ribeirão Frutal basin (Figure 1-2; Table 1). Immediately after removal from wild, individuals of several species were photographed alive in an aquarium. Vouchers were euthanized in anesthetic (i.e., benzocaine), fixed in $10 \%$ formalin, transferred to $70 \%$ alcohol and subsequently deposited in Brazilian collections: LBP (Laboratório de Biologia de Peixes, Botucatu, Botucatu, SP, Brazil); NUP (Coleção Ictiológica do Núcleo de Pesquisas em Limnologia, Ictiologia e Aquicultura, Universidade Estadual de Maringá, Maringá, PR, Brazil); and UNT (Coleção de Peixes do Laboratório de Ictiologia Sistemática da Universidade Federal do Tocantins, Porto Nacional, TO, Brazil). Identifications were carried out using published literature and, when possible, with the help of a specialist in each group (see Acknowledgements section). All collections for this study were performed with permission of IBAMA (SISBIO Number 58612-1).

\section{Results}

Samples resulted in 765 individuals distributed in five orders, ten families, and 31 fish species (Table 2). Among families, Characidae was the most represented, followed by Cichlidae, and Loricariidae (Figure 3). Site four (S4) presented the highest species-richness, with 16 species (Table 3). At site nine (S9), a small tributary entering the Ribeirão Frutal near its confluence with the Rio Grande, we recorded one likely undescribed species (i.e., Satanoperca sp.; Figure 4j). Finally, we found five fish species believed to be non-native to the Ribeirão Frutal basin: Cichla cf. piquiti Kullander \& Ferreira 2006, Knodus moenkhausii (Eigenmann \& Kennedy 1903), Metynnis lippincottianus (Cope 1870), Oreochromis niloticus (Linnaeus 1758), and Poecilia reticulata Peters 1859.

\section{Discussion}

Most species found in our survey (about $87.1 \%$ ) were recorded by Langeani et al. (2007) for the upper Rio Paraná basin. However, these authors do not provide the distribution of species within the basin (see Langeani et al. 2007). Therefore, we contribute to the knowledge of the distribution of species into the Ribeirão Frutal basin, in the upper Rio Paraná system.

Recently, Santos et al. (2017) provided a list of species from two regions of the lower rio Preto, Rio Grande basin, in the upper Paraná system; relatively near the Ribeirão Frutal basin. These authors found representatives of the order Characiformes, Gymnotiformes, Cyprinodontiformes, Perciformes (=Cichliformes herein), Siluriformes, and Synbranchiformes (see Santos et al. 2017 for more details). In this work, we did not find any representatives of Gymnotiformes. As species of this order occur in the Rio Grande basin (Santos et al. 2017; see also Castro et al. 2004), it is possible that species of this order also occur at the present study location, but were merely not sampled.

Langeani et al. (2007) showed that Characidae and Loricariidae, in general, are the two most species-rich families of the upper Rio Paraná basin. In addition, several ichthyofaunal surveys (e.g., Pavanelli et al. 2007, Smith et al. 2007, Oliveira et al. 2009, Fagundes et al. 2015, Hoffmann et al. 2015, Cardoso et al. 2016, Frota et al. 2016, Santos et al. 2017) show this pattern in tributaries of the basin. However, in our work Cichlidae was the second most represented family (Fig. 3); probably due to the presence of two non-native species of this family (i.e., Cichla cf. piquiti and Oreochromis niloticus).

Satanoperca sp. (Fig. 4j) is probably the undescribed species previously mentioned by Ota (2013). According to Ota (2013), this species occurs in the Tocantins/Araguaia and upper Rio Paraná basins, but there is no certainty as to whether or not it is native to the upper Paraná basin. On the other hand, Astyanax sp. is very similar to

Table 1. Sampled localities in the Ribeirão Frutal basin, upper Rio Paraná system, Brazil.

\begin{tabular}{|c|c|c|}
\hline Site & Coordinates & Remarks \\
\hline S1 & $20^{\circ} 0^{\prime} 14.97^{\prime \prime S}, 48^{\circ} 55^{\prime} 33.76^{\prime \prime} \mathrm{W}$ & $\begin{array}{l}\text { A tributary of left side of the Ribeirão Frutal; known as "Córrego do Jaó". It presents sections with } \\
\text { riparian vegetation. A stretch upstream is dammed and forms a small reservoir. Near to the tributary } \\
\text { there is an expansion of the urban perimeter. }\end{array}$ \\
\hline S2 & $19^{\circ} 56^{\prime} 13.50^{\prime \prime} \mathrm{S}, 48^{\circ} 56^{\prime} 56.50^{\prime \prime} \mathrm{W}$ & Site in the upper portion of main channel of the Ribeirão Frutal. \\
\hline $\mathrm{S} 3$ & $20^{\circ} 00^{\prime} 36.1^{\prime \prime} \mathrm{S}, 48^{\circ} 56^{\prime} 39.3^{\prime \prime} \mathrm{W}$ & A small tributary of right side of the Ribeirão Frutal. Unknown name. \\
\hline S4 & $20^{\circ} 00^{\prime} 19.9^{\prime \prime} \mathrm{S}, 48^{\circ} 56^{\prime} 37.2^{\prime \prime} \mathrm{W}$ & $\begin{array}{l}\text { Site in the middle portion of main channel of the Ribeirão Frutal. Region subject to the expansion } \\
\text { of the urban perimeter. }\end{array}$ \\
\hline S5 & $20^{\circ} 03^{\prime} 50.2^{\prime \prime} \mathrm{S}, 48^{\circ} 56^{\prime} 49.6^{\prime \prime} \mathrm{W}$ & $\begin{array}{l}\text { Lower portion of left tributary of the Ribeirão Frutal; known as "Córrego do Marianinho". Its } \\
\text { headwater is the target of the expansion of the urban perimeter. }\end{array}$ \\
\hline S6 & $20^{\circ} 01^{\prime} 13.25^{\prime \prime S}, 48^{\circ} 56^{\prime} 25.08^{\prime \prime} \mathrm{W}$ & $\begin{array}{l}\text { A tributary of left side of the Ribeirão Frutal; known as "Vertente Grande". This tributary has much } \\
\text { of its course within the urban perimeter (with sections channeled by cement). There are evidences } \\
\text { that the tributary receives domestic effluents. }\end{array}$ \\
\hline S10 & $20^{\circ} 04^{\prime} 25.3^{\prime \prime} \mathrm{S}, 48^{\circ} 57^{\prime} 02.4^{\prime \prime} \mathrm{W}$ & Left side tributary of the Ribeirão Frutal; known as "Córrego do Sal". \\
\hline
\end{tabular}




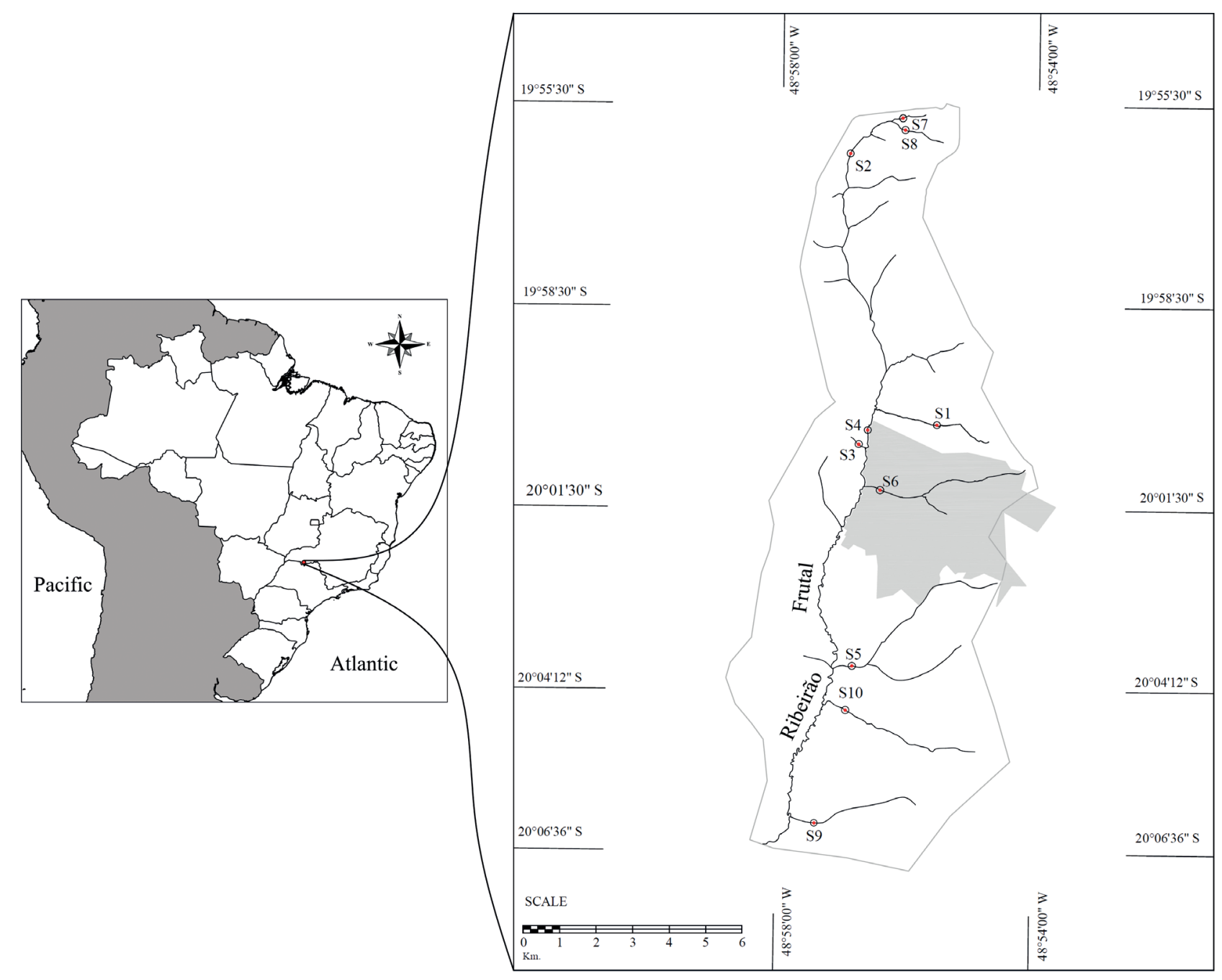

Figure 1. Map showing the Ribeirão Frutal basin with the sites sampled in the basin, upper Rio Paraná system, Brazil. Shaded area represents the urban perimeter of the Frutal municipality.

A. paranae Eigenmann, 1914. In addition, the species collected seems to have two morphotypes in the body shape. Only with further analysis, preferably including osteological and molecular data, can we certain of its specific identification.

We found a total of five non-native species in Ribeirão Frutal basin: Oreochromis niloticus, native to the Afrotropical region (Welcomme 1988), Poecilia reticulata, described based on material from "Caracas" (Peters 1859, p. 412), in Venezuela, Metynnis lippincottianus and $C$. cf. piquiti, both native to the Amazon basin (Jégu 2003, Kullander \& Ferreira 2006), and Knodus moenkhausii, which is not native to the upper Rio Paraná basin according to Langeani et al. (2007). Hyphessobrycon eques was found only in two tributaries of the Ribeirão Frutal basin (see Tab. 3). Castro et al. (2004) were not certain whether this species was native to the Rio Grande. With no evidence to suggest recent introduction of this species to the Ribeirão Frutal, we will tentatively consider it to be native. All of the five aforementioned non-native species seem to be fully-established and reproducing at the collecting sites in Ribeirão Frutal basin.

Numerous small basins of the upper Rio Paraná system have been impacted by anthropogenic activities (e.g., Santos et al. 2017, this work). Therefore, modern and comprehensive ichthyological surveys are needed to effectively document the fish fauna of these small tributary basins. Obviously, together with these surveys, measures to avoid or minimize negative impacts to these environments should be adopted. For the Ribeirão Frutal basin, in particular, we recommended three first actions: (i) management of the non-native fish species mentioned here and initiatives to avoid new introductions (e.g., Azevedo-Santos et al. 2015); (ii) avoid urban sprawl over the basin; and (iii) remove the dams (i.e., small reservoirs) in the headwater streams of the basin. 


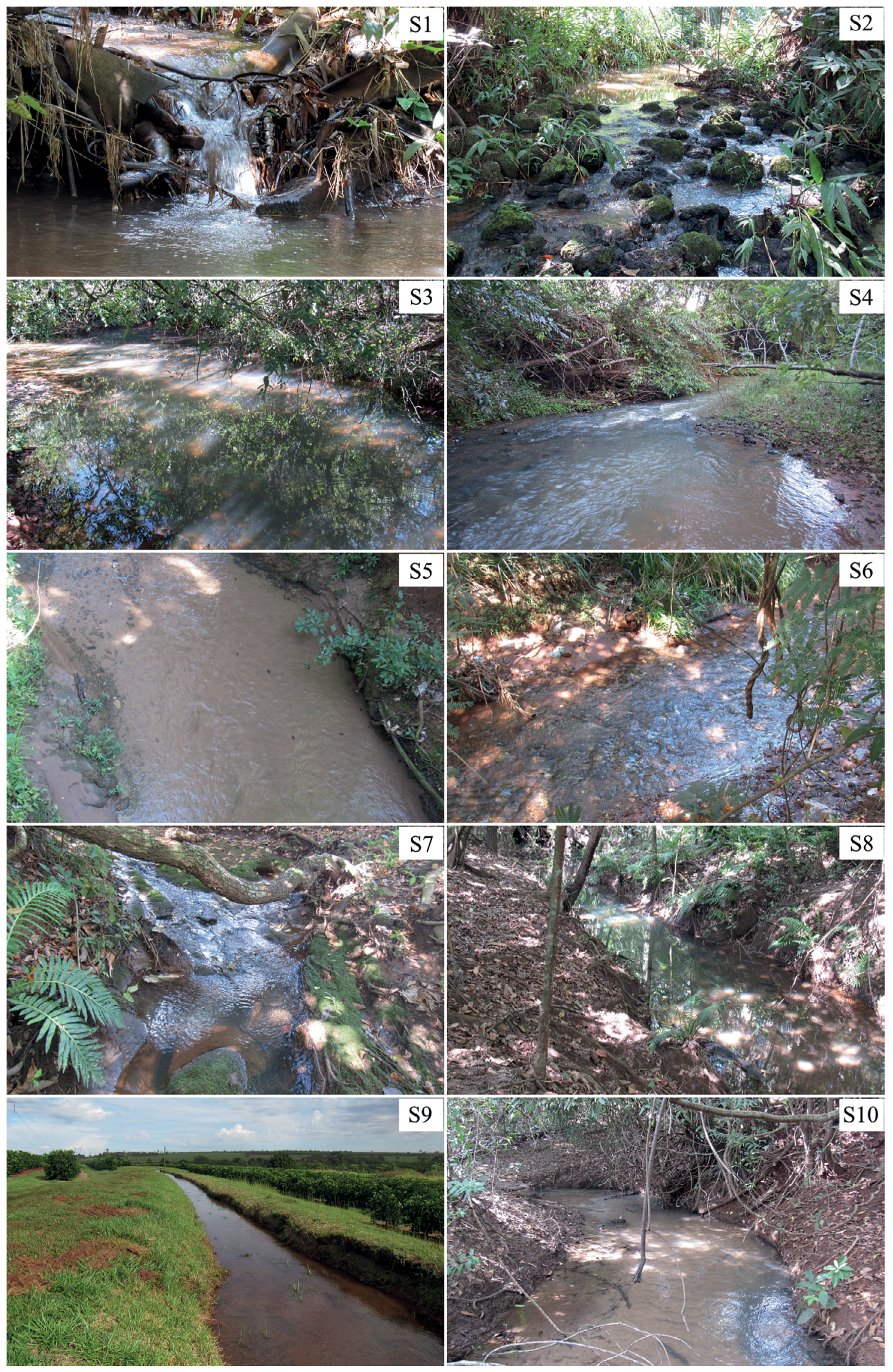

Figure 2. Photos showing stretches of each sampling site (S1 to S10) from the Ribeirão Frutal basin, upper Rio Paraná system, Brazil. 
Ichthyofauna of the Ribeirão Frutal, Brazil

Table 2. Fish species collected in the Ribeirão Frutal basin, upper Rio Paraná system, Brazil. Classifications follow Eschmeyer and Fong (2018)

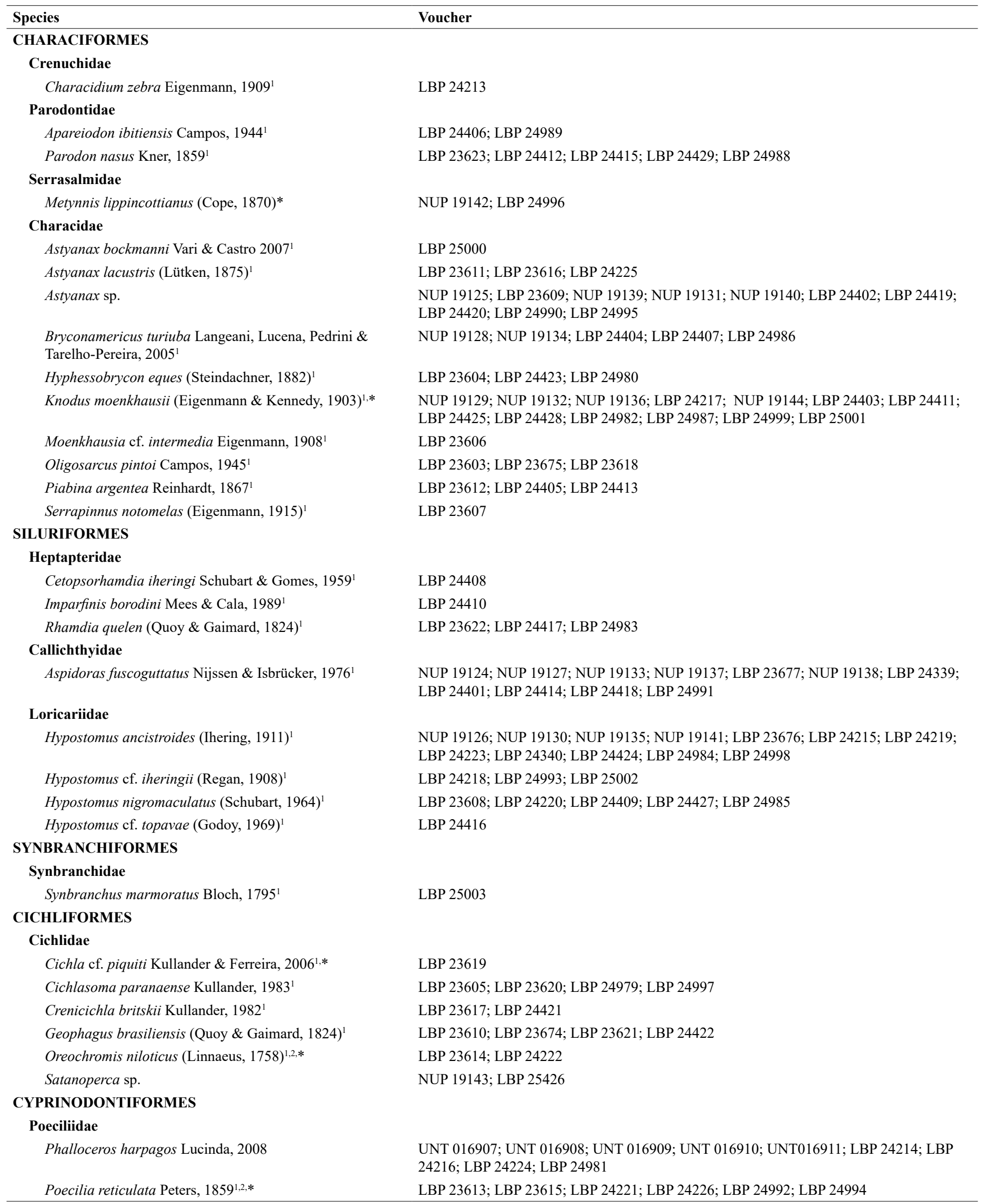

${ }^{1}$ Species recorded by Langeani et al. (2007) for the upper Rio Paraná basin. ${ }^{2}$ Species recorded (without voucher) by Azevedo-Santos \& Coelho (2017) for the Vertente Grande, Ribeirão Frutal basin. * Non-native species in the Ribeirão Frutal basin. 


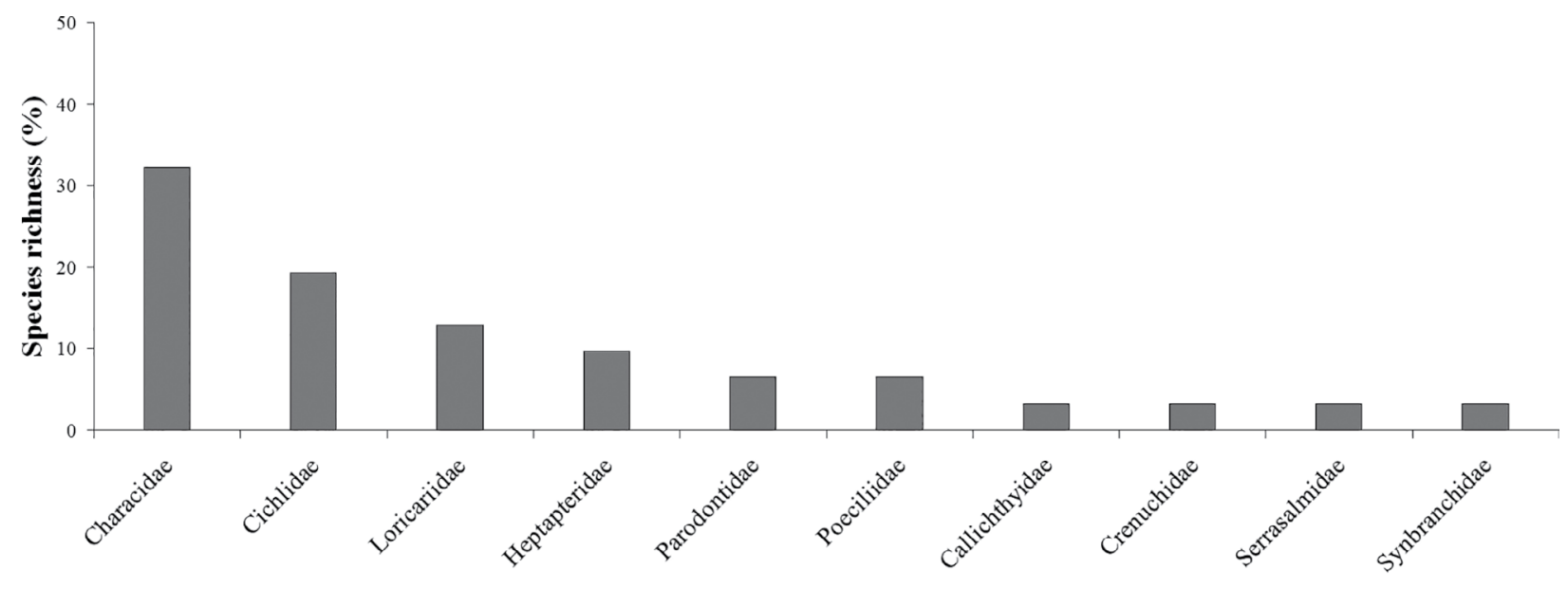

Families

Figure 3. Species richness (\%) of each fish family collected in Ribeirão Frutal basin, upper Rio Paraná system, Brazil.

Table 3. Species collected (X) in each site (S1 to S10) of the Ribeirão Frutal basin, upper Rio Paraná system, Brazil.

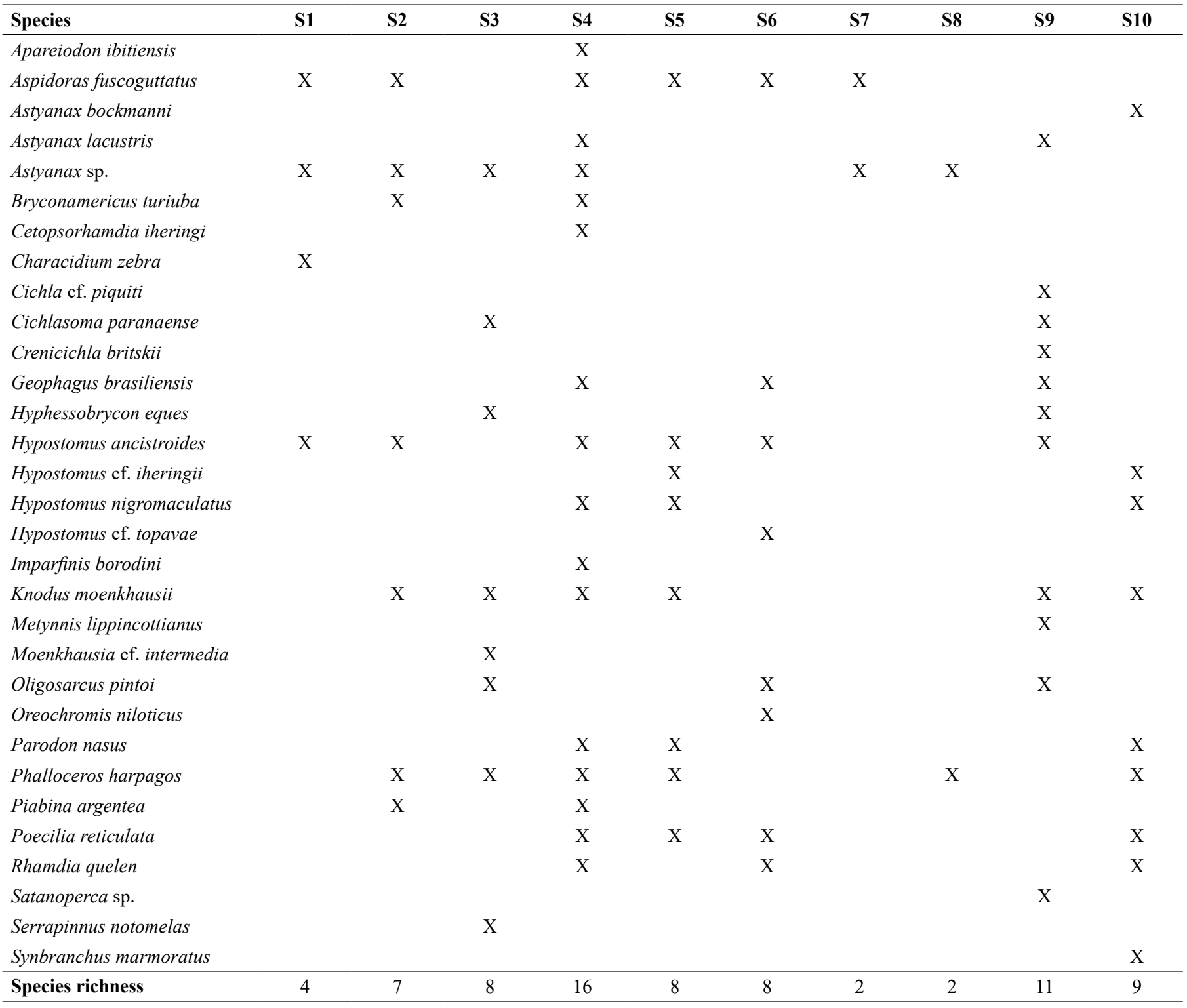




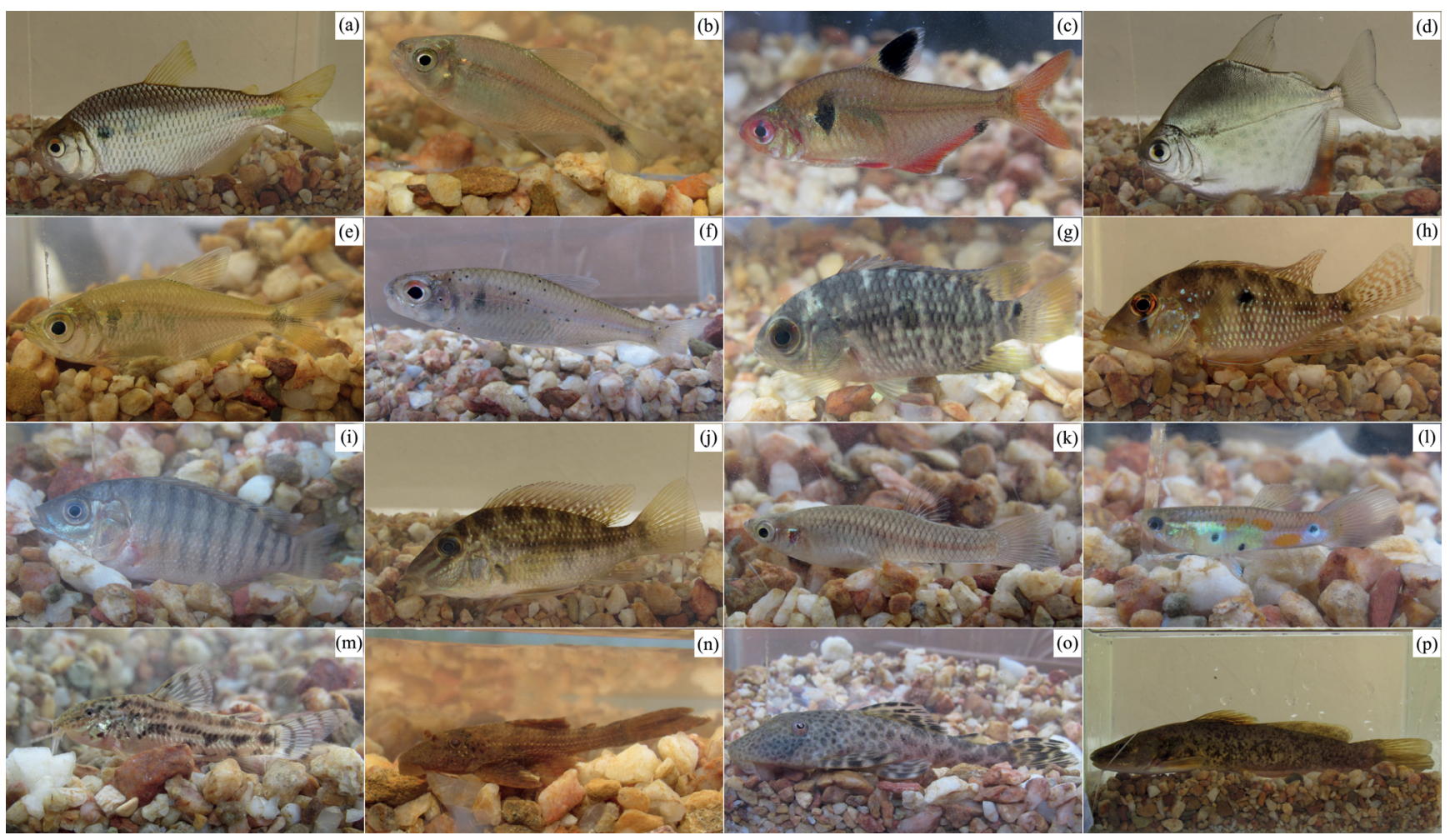

Figure 4. Live specimens representing several of the species collected in Ribeirão Frutal basin: (a) Astyanax lacustris, LBP 23616; (b) Astyanax sp., NUP 19125; (c) Hyphessobrycon eques, LBP 23604; (d) Metynnis lippincottianus, NUP 19142; (e) Oligosarcus pintoi, LBP 23603; (f) Piabina argentea, LBP 23612; (g) Cichlasoma paranaense, LBP 23605; (h) Geophagus brasiliensis, LBP 23621; (i) Oreochromis niloticus, LBP 23614; (j) Satanoperca sp., NUP 19143; (k) Phalloceros harpagos, UNT 016907; (1) Poecilia reticulata, LBP 23615; (m) Aspidoras fuscoguttatus, NUP 19127; (n) Hypostomus ancistroides, NUP 19130; (o) Hypostomus nigromaculatus, LBP 23608; (p) Rhamdia quelen, LBP 23622.

\section{Acknowledgments}

We are grateful to Paulo R. Coelho, for Fig.1 and logistical support; to Mark Sabaj (ANSP) and Maxwell J. Bernt (ULL), for providing suggestions on the manuscript; to Carlos A. M. Oliveira (NUP), for identification of Astyanax; to Claudio H. Zawadzki (NUP), for identification of Hypostomus; Paulo H. F. Lucinda (UNT), for identification of Phalloceros; Claudio Oliveira (LBP) and Carla S. Pavanelli (NUP), for curatorial assistance. Valter M. Azevedo-Santos was supported by Coordenação de Aperfeiçoamento de Pessoal de Nível Superior (CAPES), and Paula N. Coelho and Gabriel C. Deprá were supported by Conselho Nacional de Desenvolvimento Científico e Tecnológico (CNPq).

\section{Authors' Contributions}

Valter M. Azevedo-Santos formulated the idea. Valter M. AzevedoSantos and Paula N. Coelho performed the field work including collection of all the specimens. All authors collaborated with the identification, data analysis, and writing of the manuscript.

\section{Conflicts of Interest}

We, the authors, declare that we have no conflicts of interest related to the publication of this article.

\section{References}

AZEVEDO-SANTOS, V.M., PELICICE, F.M., LIMA-JUNIOR, D.P., MAGALHÃES, A.L.B., ORSI, M.L., VITULE, J.R.S. \& AGOSTINHO, A.A. 2015. How to avoid fish introductions in Brazil: education and information as alternatives. Natureza \& Conservação 13: 123-132. https:// doi.org/10.1016/j.ncon.2015.06.002

AZEVEDO-SANTOS, V.M. \& COELHO, P.N. (2017). Peixes não nativos introduzidos em um riacho do Triângulo Mineiro. In "Biomas Brasileiros: Conservação da biodiversidade, solo, floresta e água” (V.A. Rodrigues, H.E. Siqueira, P.J.D. Oliveira, L.Z. Pinheiro, L.A. Bucci, Editors.). Fundação de Estudos e Pesquisas Agrícolas e Florestais, Botucatu, p. 242-244.

BRITO, S.L., PEREIRA, T.T.C. \& MARTINS, I.C. 2017. Sediments of watersheds from Frutal and Bebedouro Streams (Frutal, MG, Brazil) as an indicator of human activities. Ambiente \& Água 12(1): 17-32.

CARDOSO, R.T., OLIVEIRA, A.K. \& GARAVELLO, J.C. 2016. Longitudinal distribution of the ichthyofauna in a tributary of Tietê River with sources on the basaltic cuestas of São Paulo, southeastern Brazil. Biota Neotropica 16(2): e20150005. http://dx.doi.org/10.1590/1676-0611-BN-2015-0005

CASTRO, R.M.C., CASATTI, L., SANTOS, H.F., MELO, A.L.A., MARTINS, L.S.F., FERREIRA, K.M., GIBRAN, F.Z., BENINE, R.C., CARVALHO, M., RIBEIRO, A.C., ABREU, T.X., BOCKMANN, F.A., PELIÇÃO, G.Z., STOPIGLIA, R. \& LANGEANI, F. 2004. Estrutura e composição da ictiofauna de riachos da bacia do rio Grande no estado de São Paulo, sudeste do Brasil. Biota Neotropica 4(1): 01-39. http://www.biotaneotropica.org.br/ v4n1/pt/abstract?article+BN01704012004

ESCHMEYER, W. N. \& FONG, J. D. 2018. SPECIES BY FAMILY/ SUBFAMILY. (http://researcharchive.calacademy.org/research/ichthyology/ catalog/SpeciesByFamily.asp). (last access 18 March 2018). 
FAGUNDES, D.C., LEAL, C.G., CARVALHO, D.R., JUNQUEIRA, N.T., LANGEANI, F. \& POMPEU, P.S. 2015. The stream fish fauna from three regions of the Upper Paraná River basin. Biota Neotropica 15(2): e20140187. http://dx.doi.org/10.1590/1676-06032015018714

FERREIRA, F. S., DUARTE, G. S. V., SEVERO-NETO, F., FROEHLICH O. \& SÚAREZ, Y. R. 2017. Survey of fish species from plateau streams of the Miranda River Basin in the Upper Paraguay River Region, Brazil. Biota Neotropica 17(3): e20170344. http://dx.doi.org/10.1590/1676-0611BN-2017-0344

FROTA, A., DEPRÁ, G.C., PETENUCCI, L.M. \& GRAÇA, W.J. 2016. Inventory of the fish fauna from Ivaí River basin, Paraná State, Brazil. Biota Neotropica 16(3): e20150151. http://dx.doi.org/10.1590/1676-0611BN-2015-0151

GIONGO, P., SAMPAIO, W.M.S., BELEI, F., CARVALHO, F.K., FERNANDES, A. \& DERGAM, J.A. 2011. Ichthyofauna of the Carrapato, Mutum and Caba Saco streams (Araguaia River Basin), Serra dos Carajás region, southeastern Pará, Brazil. Check List 7(4): 517-521.

HOFFMANN, A.C., NASCIMENTO, R.H.C. \& SHIBATTA, O.A. 2015. Fish fauna from tributaries throughout the Tibagi River basin, upper Paraná basin, Brazil. Check List 11(6): 1815

JÉGU, M. 2003. Subfamily Serrasalminae (Pacus and Piranhas). Pp. 182-196. In: REIS, R. E., S. O. KULLANDER \& FERRARIS. C. J. (Eds.). Check list of the freshwater fishes of South and Central America. Porto Alegre, Edipucrs, 2003

KULLANDER, S.O. \& FERREIRA, E.J.G. 2006. A review of the South American cichlid genus Cichla, with descriptions of nine new species (Teleostei: Cichlidae). Ichthyological Exploration of the Freshwaters 17(4): 289-398.

LANGEANI, F., CASTRO, R.M.C., OYAKAWA, O.T., SHIBATTA, O.A., PAVANELLI, C.S. \& CASATTI, L. 2007. Diversidade da ictiofauna do Alto Rio Paraná: composição atual e perspectivas futuras. Biota Neotropica 7: 181-197. http://www.biotaneotropica.org.br/v7n3/pt/ abstract?article+bn03407032007

MACHADO, R.,Q. \& AUDINO, V. 2017. Indicadores de Sustentabilidade em Agroecossistemas (ISA) - Resultados da Bacia do Ribeirão Frutal (Frutal - MG). Revista Eletrônica Multidisciplinar - FACEAR 1: 1-13. http://www.revista.facear.edu.br/artigo/\$indicadores-de-sustentabilidadeem-agroecossistemas-isa-resultados-da-bacia-do-ribeirao-frutal-frutal-mg

MELO, B.F., BENINE, R.C., BRITZKE, R., GAMA, C.S. \& OLIVEIRA, C. 2016. An inventory of coastal freshwater fishes from Amapá highlighting the occurrence of eight new records for Brazil. ZooKeys 606: 127-140.
OHARA, W.M. \& LOEB, M.V. 2016. Ichthyofauna of the upper Juruena river on Chapada dos Parecis, Mato Grosso, Brazil. Biota Neotropica 16(4): e20160224. http://dx.doi.org/10.1590/1676-0611-BN-2016-0224

OLIVEIRA, A.K., APONE, F., BIRINDELLI, J.L. \& PEREZ JÚNIOR O.R. 2009. Fish, tributaries of middle rio Mogi Guaçu, upper rio Paraná basin, São Paulo State, southeastern Brazil. Check List 5(3): 488-494.

OTA, R.R. 2013. Revisão taxonômica de Satanoperca Günther, 1862 (Perciformes, Cichlidae), com a descrição de três espécies novas. Master's thesis, Maringá, Brazil: State University of Maringá.

PAVANELLI, C.S., GRAÇA, W.J., ZAWADZKI, C.H., BRITSKI, H.A., VIDOTTI, A.P., AVELINO, G.S. \& VERÍSSIMO, S. 2007. Fishes from the Corumbá Reservoir, Paranaíba River drainage, upper Paraná River basin, State of Goiás, Brazil. Check List 3(1): 58-64.

PETERS, W. (C. H.). 1859. Eine neue vom Herrn Jagor im atlantischen Meere gefangene Art der Gattung Leptocephalus, und über einige andere neue Fische des Zoologischen Museums. Monatsberichte der Königlichen Preussischen Akademie der Wissenschaften zu Berlin 1859: 411-413.

RAIOL, R. D. O., WOSIACKI, W.B. \& MONTAG, L.F.A. 2012. Fish of the Taiassuí and Benfica river basins, Benevides, Pará (Brazil). Check List 8(3): 491-498.

SANTOS, A.C., GONÇALVES, C.C. \& CARVALHO, F.R. 2017. Ichthyofauna of the "Cachoeira de São Roberto" and fishes of lower Preto River, upper Paraná River basin, Brazil. Biota Neotropica 17(1): e20160196. http://dx.doi. org/10.1590/1676-0611-BN-2016-0196

SERRA, J.P., CARVALHO, F.R. \& LANGEANI, F. 2007. Ichthyofauna of the rio Itatinga in the Parque das Neblinas, Bertioga, São Paulo State: composition and biogeography. Biota Neotropica 7(1): 81-86. http://dx.doi.org/10.1590/ S1676-06032007000100011

SILVA-OLIVEIRA, C., CANTO, A.L.C. \& RIBEIRO, F.R.V. 2016. Stream ichthyofauna of the Tapajós National Forest, Pará, Brazil. ZooKeys 580: 125-144.

SILVEIRA, L.F., BEISIEGEL, B.M., CURCIO, F.F., VALDUJO, P.H., DIXO, M., VERDADE, V.K., MATTOX, G.M.T. \& CUNNINGHAM, P.T.M. 2010. What use do fauna inventories serve?. Estudos avançados 24(68): 173-207.

SMITH, W.S., PETRERE JR, M. \& BARRELLA, V. 2007. Fishes, Sorocaba river sub-basin, State of São Paulo, Brazil. Check List 3(3): 282-286.

VIDOTTO-MAGNONI, A.P., GARCIA, D.A.Z., COSTA, A.D.A., SOUZA, J.G., YABU, M.H.S., ALMEIDA, F.S. \& ORSI, M.L. 2015. Ichthyofauna of streams of the Lower Paranapanema River basin, state of Paraná, Brazil. Check List 11(5): 1756

WELCOMME, R.L. 1988. International introductions of inland aquatic species. 294 ed. FAO Fisheries Technical Paper. 